\title{
Blaise Pascal
}

\section{Hugsanir \\ Um Hugsanir eftir Blaise Pascal: inngangur að pýðingu}

Blaise Pascal fæddist í bænum Clermont í Frakklandi árið 1623 og ólst upp hjá föður sínum sem sá um menntun hans og tveggja systra hans. Móðir hans féll frá pegar hann var ungur að árum. Nokkru síðar flutti fjölskyldan til Parísar og paðan til Rúðuborgar um skeið. Pascal varð snemma pekktur fyrir stærðfræðihæfileika sína og er talinn með helstu stærðfræðingum 17. aldar. Áður en hann náði sextán ára aldri vöktu skrif hans um rúmfræði athygli og aðdáun vísindamanna í höfuðborginni sem faðir hans umgekkst í hinni svokölluðu Mersenne-stærðfræðiakademíu. Innan við tvítugt hófst Pascal handa við gerð reiknivélar, „la roue pascale“ eða „paskalhjólið“. Hann fann upp líkindareikning og samdi ýmar ritgerðir um rannsóknir sínar á sviði raunvísinda, meðal annars um tómið, príhyrninga og loftprýsting, svo eitthvað sé nefnt.

Pascal mun ekki hafa alist upp við sérstaka trúrækni en fyrsta vakning hans í peim efnum varð árið 1646 pegar öll fjölskyldan ákvað að taka upp kristilegra líferni í kjölfar veikinda föðurins. Við fráfall hans gekk Jacqueline, yngri systirin, í klaustrið í Port-Royal des Champs í nágrenni Parísar. Pascal hellti sér út í rannsóknir og var í sambandi við ýmsa pekkta samtímamenn sína í Frakklandi, svo sem René Descartes og Pierre de Fermat. Hann kynntist efahyggju og fríhyggju, sem pá var nokkuð útbreidd, en fríhyggjumenn drógu í efa heimsmynd og boðskap kristninnar. Pann 23. nóvember 1654, frá klukkan hálfellefu um kvöld til klukkan hálfeitt eftir miðnætti, varð Pascal svo fyrir sterkri trúarlegri hugljómun sem hafði mikil áhrif á líf hans og hugsun pótt hann hafi ekki kosið að snúa baki við veraldlegu lífi eða

\begin{tabular}{|c|c|c|}
\hline & $\begin{array}{l}\text { (C) } 2020 \text { Ritið, tímarit Hugvísindastofnunar } \\
\text { og höfundur greinarinnar }\end{array}$ & $\begin{array}{l}\text { Birtist á vefnum http://www.ritid.hi.is. } \\
\text { Tengiliður: ritið@hi.is }\end{array}$ \\
\hline $\begin{array}{l}\text { Ritið } \\
\text { tbl. 20. árg. } 2020(179-202) \\
\text { Pýðing }\end{array}$ & $\begin{array}{l}\text { Útgefandi: } \\
\text { Hugvísindastofnun Háskóla Íslands, } \\
\text { Sæmundargötu 2, } 102 \text { Reykjavík }\end{array}$ & $\begin{array}{c}\text { DOI: } 10.33112 / \text { ritid.20.3.7 } \\
\text { Birt samkvæmt skilmálum } \\
\text { Creative Commons BY (4.0). }\end{array}$ \\
\hline
\end{tabular}


leggja vísindarannsóknir sínar á hilluna í kjölfarið. Hann skrifaði í tvígang niður lýsingu, sem hann kallar Mémorial, á vitruninni og hefst hún á orðinu Feu eða eldur: „Eldur, Guð Abrahams, Guð Ísaks, Guð Jakobs, ekki heimspekinga og menntamanna. Fullvissa, fullvissa, tilfinning, gleði, friður.“

Á síðari hluta 17. aldar, í kjölfar siðbótar og trúarbragðastríða, ríktu djúpstæðar deilur um trúmál í Frakklandi. Pær snerust meðal annars um hina guðlegu náð og hverjum hún félli í skaut og hvers vegna. Jesúítar og jansenistar voru fulltrúar andstæðra sjónarmiða. Hreyfing jesúíta, sem stofnuð var sem andsvar kapólsku kirkjunnar við siðbótarhugmyndum Lúthers og Kalvíns, bauð villuráfandi sauðum aflausn og fyrirgefningu ef peir játuðu syndir sínar og sýndu iðrun. Pannig var hægt að ganga að náðinni vísri, sama hvernig einstaklingurinn hafði hagað lífi sínu. Jansenistar höfðu aðra sýn í pessum efnum. Peir aðhylltust kenningar flæmska guðfræðingsins Cornelíusar Jansen en hann var höfundur verksins Augustinus sem kom út árið 1640. Eins og heiti verksins gefur til kynna var Janseníus undir sterkum áhrifum af kenningum Ágústínusar kirkjuföður og í ritinu boðaði hann afturhvarf til hugmynda hans um kristna trú. ${ }^{1}$ Hann fjallaði meðal annars um áhrif syndafallsins á mannlegt eðli: hinn spillti (fallni) maður er veikgeðja og sjálfhverfur og aðeins hinir útvöldu munu öðlast náð Guðs. Pessi dökka og vonlitla mynd af manninum pótti líkjast hugmyndum kalvínista sem farið höfðu halloka í trúarbragðastríðunum. Í hópi jansenista var einnig að finna andstæðinga páfans en pví var jansenisminn illa liðinn af yfirvöldum enda olli hann djúpstæðum klofningi innan kirkjunnar og samfélagsins.

Um árabil var höfuðvígi jansenista að finna í gamla klaustrinu í PortRoyal des Champs. Klaustrinu var stýrt af móður Angélique Arnauld, abbadís, en hún var systir Antoines Arnauld, guðfræðings við Sorbonne-háskóla. Systkinin voru bæði höll undir jansenisma og var Arnauld ásakaður um villutrú vegna skrifa sinna til varnar Corneliusi Jansen og afstöðu sinnar í deilunni um hina guðlegu náð. Pascal blandaði sér í umræðuna og skrifaði samtals átján nafnlaus bréf par sem hann tók upp varnir fyrir Arnauld og skoðanir hans og deildi á jesúítana. Fyrstu tíu bréfin voru stíluð á ímyndaðan vin á landsbyggðinni, sex bréf voru stíluð á jesúítana og pau tvö síðustu á skriftaföður konungs. Fyrsta bréfið, Première Provinciale, birtist í janúar 1656 og bað síðasta í marsmánuði 1657. Bréfin voru prentuð ólöglega af ýmsum prenturum; bau voru víðlesin og vöktu athygli fyrir einfaldan og hárbeittan stíl og urðu einnig til pess að gera kenningar jansenistanna skiljanlegri al-

Um áhrif Ágústínusar á hugsun og bókmenntir á 17. öld, sjá til dæmis Philippe Sellier, Pascal et saint Augustin, París: Armand Colin, 1970. 
menningi. Saman mynda pau hið pekkta verk Les lettres provinciales (Bréf til vinar á landsbyggðinni). Eftir bréfaskrifin sneri Pascal sér aftur að vísindunum en einnig að undirbúningi verks til varnar trúnni sem hann náði ekki að ljúka við áður en hann féll frá, 39 ára gamall. Giberte, eldri systir hans, skrifaði ævisögu bróður síns, Vie de Monsieur Pascal, nokkrum árum eftir andlát hans. ${ }^{2}$ Fyrir áhrif jesúíta lét Loðvík XIV loka klaustrinu í Port-Royal árið 1709 og premur árum síðar var pað jafnað við jörðu.

Pegar Blaise Pascal lést árið 1662 hafði hann ekki náð að klára öll pau verk sem hann hafði lagt drög að. Eitt peirra var ritið Apologie de la religion chrétienne eða Til varnar kristinni trú sem nú er pekkt undir heitinu Pensées eða Hugsanir. Pascal hafði safnað saman hugsunum sínum um efnið um árabil og helgað pví síðasta árið sem hann lifði. Hann skrifaði á stórar arkir en hann mun hafa klippt pær niður í brot pegar hann kynnti fyrirhugað verk sitt í erindi í Port-Royal árið 1658. Fyrsta útgáfan bar heitið Pensées de $M$. Pascal sur la Religion, et sur quelques autres sujets, qui ont esté trouvées aprés sa mort parmy ses papiers (Hugsanir M. Pascals um trúna, og nokkur önnur málefni, sem fundust í blöðum hans eftir andlát hans) og kom hún út í París í janúarmánuði 1670. ${ }^{3}$ Par hafði peim brotum sem póttu skýrust verið safnað saman og raðað upp með ýmsum leiðréttingum. Sú útgáfa var gagnrýnd par sem texta Pascals hafði sumstaðar verið breytt og mörgum brotum sleppt. Hugsanir hafa verið endurútgefnar í nokkur skipti en verkefnið er vandasamt par sem Pascal strikaði víða yfir orð og bætti öðrum við; auk pess er rithöndin ógreinileg og greinarmerkjanotkun lítil. ${ }^{4}$ Í hverri nýrri gerð er einhverjar breytingar að finna, ekki síst á uppröðun brotanna. Meðal peirra var auk pess eitt og annað sem hafði lítið eða ekkert með varnarræðuna að gera: vangaveltur um ýmis málefni og önnur verk, persónulegar hugleiðingar, minnispunktar og glósur. Brotin veita pví afar forvitnilega innsýn í hugsun Pascals og vinnubrögð.

Раð er ekki fullbúin ræða til varnar kristni sem lesandinn finnur í Hugs-

2 „La Vie de Monsieur Pascal, écrite par Madame Périer, sa sœur, femme de Monsieur Périer, conseiller de la cour des aides de Clermont", Pascal, Euvres complètes, préface d'Henri Gouhier, présentation et notes de Louis Lafuma, París: Aux Éditions du Seuil, 1963, bls. 17-33.

3 Pensées de M. Pascal sur la Religion, et sur quelques autres sujets, qui ont esté trouvées aprés sa mort parmy ses papiers, París: Chez Guillaume Desprez, 1669.

4 Um skipulag og skýrleika handritsins eru skiptar skoðanir, sjá til dæmis Louis Lafuma, „Introduction“, Pascal, Euvres complètes, préface d'Henri Gouhier, présentation et notes de Louis Lafuma, París: Aux Éditions du Seuil, 1963, bls. 493-494. 
unum heldur brotakennd leið að óloknu verki. Рað var meðal annars skrifað með fríhyggjumenn í huga sem Pascal hafði umgengist og vildi í senn andmæla og hvetja til hugarfarsbreytingar. Stundum taka hugsanir á sig form samtals par sem ólíkar raddir skiptast á skoðunum innra með höfundi. Hann reynir til að mynda að sannfæra efahyggjumanninn, með líkindareikningi, um að veðja á trúna, vegna pess að ef Guð er til hafi hann allt að vinna en sé hann ekki til sé tap hans fólgið í pví að hafa haft rangt fyrir sér. Veðji hann hins vegar ekki á trúna og Guð reynist vera til, pá fari hann á mis við ódauðleikann, en sé Guð ekki til sé ávinningurinn sá að hafa haft rétt fyrir sér. ${ }^{5}$ Vísindamaðurinn áttar sig á smæð mannsins í alheiminum en trúmaðurinn vill gefa manninum vægi í hinu óendanlega sköpunarverki Guðs. Í Hugsunum skrifar Pascal um vanmátt skynseminnar til pess að skilja Guð, til pess að vernda manninn gegn veikleika hans og gera hlutskipti hans bærilegra í alheiminum. Hann sviptir hulunni af sjálfumgleðinni og blekkingarleiknum andspænis eymdinni sem býr innra með manninum. Hann fjallar um togstreitu hjartans og skynseminnar og er sannfærður um að hjartað hafi sín rök sem vegi pyngra en rök skynseminnar. Prátt fyrir trúarlegt yfirbragð og skoðanir, sem rekja má til ritunartíma verksins og hugðarefna höfundar, eru skrif Pascals áhrifamikil og miðla sýn höfundar á mannlegt eðli, á manninn sjálfan og stöðu hans í heimi sem hann hefur ekki forsendur til pess að skilja.

Við pýðingu á peim brotum sem hér birtast var stuðst við útgáfu Michels Le Guern sem kom út hjá Gallimard árið 1977. ${ }^{6}$ Til hliðsjónar var höfð útgáfa Louis Lafuma frá árinu $1963^{7}$ og vefútgáfa á brotum Hugsana. ${ }^{8}$ Stórir bókstafir sem birtast í pýðingunni eru vísanir Pascals til annarra kafla í handritinu, tölustafir vísa til greina innan kaflanna, litlir bókstafir eru viðbætur hans og birtast pær neðanmáls. ${ }^{9}$

\section{Asdís R. Magnúsdóttir}

5 Framsetning Pascals er talsvert flóknari og lengri og mikið hefur verið skrifað um pennan kafla Hugsana, sjá til dæmis nýlega umfjöllun og heimildaskrá hjá Alan Hájek, „Pascal's Wager“, The Stanford Encyclopedia of Philosophy (Summer 2018 Edition), ritstjóri Edward N. Zalta, 1. september 2017, sótt 20. nóvember 2020 af https://plato.stanford.edu/archives/sum2018/entries/pascal-wager/.

6 Blaise Pascal, Pensées, I, Édition présentée, établie et annotée par Michel Le Guern, París: Gallimard, 1977.

7 Pascal, Euvres complètes, préface d'Henri Gouhier, présentation et notes de Louis Lafuma, París: Aux Éditions du Seuil, 1963.

8 Dominique Descotes og Gilles Proust, L'édition électronique des Pensées de Pascal, sótt 20. nóvember 2020 af http://www.penseesdepascal.fr/.

9 Guðrúnu Kristinsdóttur, sérfræðingi í frönskum bókmenntum 16. og 17. aldar, eru færðar pakkir fyrir góðar ábendingar við íslenska pýðingu textans. 


\title{
Blaise Pascal
}

\author{
Hugsanir \\ (Nokkur brot)

\section{Leiði \\ og eiginleikar sem tilheyra manninum}

72

Dramb.

Oftast er forvitni ekki annað en hégómleiki; við viljum vita til pess eins að geta sagt frá; við legðumst ekki í siglingar ef við ætluðum ekki að segja frá peim heldur njóta ánægjunnar af ferðinni einvörðungu, án væntinga um að deila henni nokkru sinni með öðrum.

Lýsing á manninum.

Öðrum háður, práir sjálfstæði, hefur parfir.

74

Leiðinn sem fylgir pví að fara frá peirri iðju sem við höfum bundist. Karlmaður á ánægjuríkt líf í hjónabandi sínu; ef hann sér konu sem fellur honum vel í geð og ef hann leikur sér í fimm eða sex daga og er ánægður, pá verður hann vesæll við pað að taka aftur upp fyrri iðju. Ekkert er hversdagslegra en petta. 


\section{Mikilfengleiki}

\section{6}

Ef dýr gerði af hugsun pað sem pað gerir af eðlishvöt, og ef dýr segði með hugsun pað sem pað segir af eðlishvöt varðandi veiðar og til pess að láta félaga sína vita að bráðin sé fundin eða týnd, pá myndi dýrið einnig tjá sig um hluti sem snerta pað nánar, eins og til að segja: „Nagið petta reipi sem særir mig og sem ég næ ekki til.“

\section{7}

Mikilfengleiki.

Ástæður afleiðinganna eru til marks um mikilfengleika mannsins, pað að hafa búið til úr girndinni svo fallega skipan.

98

Goggur páfagauksins sem hann strýkur af pótt hann sé hreinn.

99

Hvað er pað í okkur sem finnur ánægju? Er pað höndin, er pað handleggurinn, er pað holdið, er pað blóðið? Við munum sjá að pað hlýtur að vera eitthvað óefnislegt.

Á móti efahyggjunni.

Við gerum ráð fyrir að allir skilgreini pau á sama hátt. ${ }^{10}$ En pessi afstaða okkar á sér enga stoð, pví við höfum enga sönnun um að svo sé. Mér er ljóst að pessi orð eru notuð við sömu tækifæri, og að í hvert sinn sem tveir menn sjá hlut færast úr einum stað í annan tjá peir pað sem peir sjá með sama orði og segja báðir að hann hafi færst til, og út frá pessu samræmi drögum við sterka ályktun um samræmi hugmynda, en pað er ekki fullkomlega og óyggjandi sannfærandi pótt vel megi veðja um að svo sé, par sem við vitum að við komumst iðulega að sömu niðurstöðu út frá ólíkum tilgátum.

Petta nægir að minnsa kosti til að flækja málið, ekki pó pannig að pað

10 „Pau“ vísar hér til orða eins og rúm, tími, hreyfing, sem samkvæmt Pascal útskýra sig sjálf en verða torskildari ef reynt er að útskýra pau, sjá Blaise Pascal, Pensées, I, bls. 274. 
slökkvi algerlega hið náttúrulega ljós sem fullvissar okkur um pessa hluti. Akademíkerarnir hefðu veðjað, en slíkt er til pess fallið að slá fölva á ljósið og koma kennisetningarmönnum úr jafnvægi, til dýrðar leynimakki efahyggjumannanna sem felst í pessari tvíræðu tvíræðni, og í vissu tvísýnu myrkri sem efi okkar getur ekki firrt öllu ljósi og sem náttúrulegar gáfur okkar geta ekki svipt öllu myrkri.

\section{1}

Við pekkjum sannleikann ekki eingöngu af skynsemi heldur einnig með hjartanu. Раð er með hjartanu sem við pekkjum frumforsendurnar og pað er ekki til neins fyrir skynsemina, sem er ekki ein peirra, að reyna að berjast gegn peim. Efahyggjumenn hafa petta eina markmið og vinna ötullega að pví, án árangurs. Við vitum að okkur er ekki að dreyma, pótt við séum ófær um að sýna fram á bað af skynsemi; pessi vangeta sannar ekki annað en léttvægi skynseminnar, en ekki óáreiðanleika allrar pekkingar okkar, eins og peir halda fram. Vegna pess að pekking á frumforsendunum, eins og að til séu rúm, tími, hreyfing og tölur, <er> jafn traust og öll sú pekking sem skynsemin færir okkur og pað er á pessari pekkingu hjartans og innsæis sem skynsemin á að hvíla og byggja sína orðræðu. Hjartað finnur að pað eru prjár víddir í rúminu og að tölurnar eru óendanlega margar og síðan sýnir skynsemin að ekki eru til neinar tvær tölur í öðru veldi par sem önnur er tvöfalt stærri en hin. Forsendurnar finnur maður innra með sér, um tilgátur er hægt að komast að niðurstöðu og allt gerist petta með vissu prátt fyrir að ólíkar leiðir séu farnar. $\mathrm{Og}$ pað er jafn tilgangslaust og fáránlegt að skynsemin krefji hjartað um sannanir fyrir pessum frumforsendum til pess að geta verið sammála, og ef hjartað krefði skynsemina um tilfinningu fyrir öllum peim tilgátum sem hún sannar til pess að geta meðtekið pær.

Pessi vangeta á pví að pjóna peim tilgangi einum að niðurlægja skynsemina, sem vill leggja dóm á alla hluti, en ekki að ráðast að fullvissu okkar eins og pað væri skynsemin ein sem gæti uppfrætt okkur. Megi Guð hins vegar gera okkur kleift að hafa aldrei pörf fyrir hana og að geta pekkt alla hluti af innsæi og tilfinningu! En náttúran neitaði okkur um pann munað; pvert á móti pá lét hún okkur aðeins í té mjög litla pekkingu af pessu tagi; allrar annarrar pekkingar purfum við að afla okkur með skynseminni.

Og af peim sökum eru peir sem Guð hefur fært Trúna af tilfinningu hjartans sælir og sannfærðir með réttu; en peim sem ekki hafa trúna er einungis hægt að færa hana með röksemdafærslu, par til Guð gefur peim hana 
með tilfinningu hjartans, pví ella er trúin aðeins mannleg og gagnslaus til sáluhjálpar.

102

Ég get vel hugsað mér mann án handa, fóta eða höfuðs vegna pess að pað er einungis reynslan sem kennir okkur að höfuðið sé nauðsynlegra en fæturnir. En ég get ekki hugsað mér manninn án hugsunar. Hann væri steinn eða skepna.

103

Eðlishvöt og skynsemi, einkenni tveggja náttúra.

104

Hugsandi reyr.

Pað er ekki í rýminu sem ég mun finna verðleika minn heldur í stjórnun hugsana minna. Ég hef engan ávinning af pví að eiga jarðir. Með rýminu umlykur alheimurinn mig og gleypir eins og punkt; með hugsuninni er pað ég sem umlyk hann.

105

Mikilfengleiki mannsins er fólginn í pví að vita að hann er vesæll; tré veit ekki að pað er vesælt.

Maðurinn er vesæll af pví hann veit að hann er vesæll en maðurinn er mikill af pví hann veit að hann er vesæll.

Óefnisleiki sálarinnar.

Heimspekingarnir sem hafa náð stjórn á ástríðum sínum, hvaða efni hefur tekist pað?

107

Öll pessi vesöld dregur fram mikilfengleika hans. Petta er vesöld háttsetts herra, vesöld konungs sem hefur verið steypt af stóli. 
Mikilfengleiki mannsins.

Mikilfengleiki mannsins er svo auðsær að hann er greinilegri en eymd hans vegna pess að pað sem er eðli hjá dýrum köllum við eymd hjá manninum: pannig getum við séð að nú er eðli hans eins og eðli dýra, áður fyrr var eðli hans betra en hann hefur glatað pví.

Hver er leiður yfir pví að vera ekki konungur nema konungur sem steypt hefur verið af stóli? Var Paul Émile óhamingjusamur yfir pví að vera ekki konsúll? Pvert á móti, allir töldu að hann væri hamingjusamur yfir pví að hafa verið konsúll, vegna pess að hlutskipti hans var ekki að gegna ávallt peirri stöðu. En öllum fannst Perseifur fjarska ólánsamur yfir pví að vera ekki lengur konungur; par sem hlutskipti hans var að vera pað alla tíð furðaði fólk sig á pví að hann skyldi afbera pað að vera á lífi. Hver lítur á pað sem ólán að hafa ekki nema einn munn og hver liti ekki á pað sem ólán að hafa ekki nema eitt auga? Engum hefur líklega komið til hugar að kveinka sér yfir bví að hafa ekki prjú augu, en við værum óhuggandi ef við hefðum ekkert auga.

109

Mikilfengleiki mannsins í girnd sinni er að hafa verið fær um að hafa á henni aðdáunarverða stjórn og að hafa gert úr henni birtingarmynd náungakærleikans. 


\section{Skemmtun}

Skemmtun.

Ef maðurinn væri hamingjusamur, væri hamingja hans pví meiri sem hann nyti minni skemmtunar, líkt og dýrlingarnir og Guð.

- Já, en er ekki hamingjan fólgin í pví að geta glaðst yfir skemmtun?

- Nei, vegna pess að hún kemur annars staðar frá og að utan; og pannig er hann háður henni og á par af leiðandi á hættu að láta glepjast af ótal hlutum, sem valda óhjákvæmilegum pjáningum.

Skemmtun.

Par sem mennirnir hafa ekki getað fundið lækningu við dauðanum, vesöld og fáfræði, hafa peir tekið pað ráð, til pess að vera hamingjusamir, að beina huganum í aðra átt.

Prátt fyrir bessa vesöld vill maðurinn vera hamingjusamur, og vill ekki vera nema hamingjusamur, og er ekki pess megnugur að vilja ekki vera pað.

En til hvaða ráða getur hann gripið? Ef vel ætti að vera pyrfti hann að gerast ódauðlegur en pað getur hann ekki og pví greip hann til pess ráðs að beina huganum í aðra átt.

125

Ég finn að ég gæti hafa ekki verið til, vegna pess að sjálfið býr í hugsun minni: af pví leiðir að ég sem hugsa hefði ekki orðið til ef móðir mín hefði dáið áour en ég fór að draga andann; af pví leiðir að ég er ekki nauðsynleg vera. Ég er heldur ekki eilífur eða óendanlegur en mér er vel ljóst að í náttúrunni er ein vera sem er nauðsynleg, eilíf og óendanleg.

Skemmtun.

Á stundum, pegar ég hef velt fyrir mér ýmsum tegundum af glundroða meðal mannanna og erfiðleikunum og hættunum sem peir mæta, bæði við hirðina og í stríðum, par sem til verða svo margar deilur, ástríður og djörf en gjarnan óheppileg áform, hef ég oft látið pau orð falla að öll óhamingja mannanna eigi sér eina rót og hún er sú að geta ekki haldið kyrru fyrir inni í einu herbergi. Ef maður sem á nóg til hnífs og skeiðar væri fær um og fús 
til pess að vera heima hjá sér, færi hann ekki paðan út til pess að sigla út á sjó eða hefja umsátur; hann yrði sér ekki út um embætti í hernum fyrir fúlgur fjár nema vegna pess að honum pætti óbærilegt að vera um kyrrt í borginni; maður gefur sig ekki á tal við aðra og leitar ekki að skemmtun í leikjum nema maður uni sér ekki heima við.

En pegar ég gaumgæfði petta nánar og eftir að hafa fundið uppsprettu allrar okkar óhamingju vildi ég finna hvað olli henni og ég komst að pví að pað er ein raunveruleg ástæða, sem felst í náttúrulegri ógæfu dauðlegs og veikgeðja hlutskiptis okkar, og hún er svo aumkunarverð að ekkert getur sefað okkur pegar við gefum pví nánari gætur.

Раð er sama hvaða hlutskipti við ímyndum okkur, með öllum peim auði sem pví gæti fylgt, pá er konungdæmið æðst og fegurst peirra allra; ekki síst pegar við ímyndum okkur öll pau fríðindi sem pví fylgja. Ef konungurinn hefur ekkert sér til skemmtunar og ef hann hefur næði til pess að hugsa um og velta pví fyrir sér hvað hann er, mun pessi munarblíða sæla ekki veita honum neina vörn; ekkert getur hindrað hann í að hugsa um uppreisnir sem gætu ógnað honum, um dauða og sjúkdóma sem ekki er hægt að forðast, pannig að ef hann er án pess sem kallað má skemmtun er hann vansæll, og vansælli en auðmjúkasti pegn hans sem leikur sér og skemmtir. H.

Раð er ástæða pess að peningaspil og félagsskapur kvenna, stríðsrekstur og háttsett embætti eru svo eftirsótt. Рað er ekki vegna pess að par sé að finna hamingju eða vegna pess að maður ímyndi sér að raunveruleg sæla sé í pví fólgin að eiga peninga sem hægt er að vinna í spilum, eða með pví að elta hlaupandi héra ${ }^{11 a}$; maður tæki ekki við honum ef hann væri gefins. Рað er ekki pessi átakalitla og friðsæla tilvera, sem fær okkur til að hugsa um okkar auma hlutskipti, sem við sækjumst eftir, eða hættan sem felst í stríðsrekstri, eða erfiðið sem fylgir vinnunni; pað er kliðurinn og ónæðið sem kemur í veg fyrir að við hugsum um hlutskipti okkar og sem styttir okkur stundir.

Рað er af peim sökum að menn eru svo hrifnir af hávaða og látum. Раð er af peim sökum að fangelsi er svo mikið kvalræði. Раð er af peim sökum að ánægja einverunnar er óskiljanleg. Og að lokum pá er mesti gleðigjafinn í hlutskipti konunga sá að við reynum án afláts að skemmta peim og bjóða peim upp á alls kyns ánægjuefni. ${ }^{12 b}$

Svona hafa mennirnir fundið upp á ýmsu til að gera sig hamingjusama.

11 a Pað er ástæða pess að við finnum meiri ánægju í pví að elta dýrið en að ná pví.

12 b Konungurinn er umkringdur fólki sem hugsar um pað eitt að skemmta honum og koma í veg fyrir að hann leiði hugann að sjálfum sér. Vegna pess að hann er vansæll, pótt hann sé konungur, ef hann leiðir hugann að pví. 
Og peir sem pykjast vera heimspekingar í ofanálag og halda að fólk, sem eyðir öllum deginum í að hlaupa á eftir héra sem pað myndi ekki borga fyrir, sé nánast rúið allri skynsemi, peir pekkja vart eðli okkar. Pessi héri getur ekki varið okkur fyrir hugsunum um dauðann og peirri vesæld sem dreifir huga okkar frá honum, en pað geta veiðarnar gert. ${ }^{13 a}$ A. ${ }^{14 b}$

Og pví er pað svo að pegar peim er bent á að pað sem peir leita að svo ákaflega geti ekki uppfyllt væntingar peirra, og ef peir svöruðu eins og peim bæri ef peir væru vel penkjandi, að peir væru aðeins á höttunum eftir ofsafenginni og ofbeldisfullri dægrastyttingu sem beindi hugsunum peirra frá peim sjálfum og að pað væri pess vegna sem peir settu sér eftirsóknarvert markmið sem hrifi pá og vekti með peim ákefð, pá yrðu andstæðingar peirra orðlausir. ${ }^{15 c}$ En peir svara ekki með pessum hætti vegna pess að peir pekkja sig ekki sjálfir. Peir vita ekki að pað sem peir sækjast eftir í raun er eftirförin en ekki bráđin sjálf. ${ }^{16 d}$

Peir ímynda sér að ef peim tækist að fá ákveðna stöðu gætu peir notið pess að hvíla sig og peir skynja ekki óseðjandi eðli græðginnar sem peir eru haldnir; peir trúa í einlægni að peir leiti hvíldar en í raun leita peir aðeins erils. Í peim býr leynd hvöt sem fær pá til að leita að skemmtun og dægrastyttingu fyrir utan pá sjálfa, og sem stafar af gremjunni yfir stöðugri vesæld peirra. Og í peim býr önnur leynd hvöt sem eru leifar mikilleika okkar upprunalegu náttúru og hún gerir peim kleift að skilja að hamingjan er einungis í kyrrðinni og ekki í glundroðanum. Af pessum tveimur andstæðu hvötum móta peir sundurlausa ráðagerð sem peir koma ekki auga á innst í sálarkimum sínum og hún fær pá til að leita sér hvíldar með pví að vera sífellt að, og að ímynda sér að peir finni fullnægjuna sem peir búa ekki yfir ef peir komast yfir ákveðna erfiðleika og að pá muni peir geta lokið upp gáttum hvíldarinnar. Svona líður ævin: við leitum hvíldar með pví að berjast við hindranir, og takist okkur að komast yfir pær er hvíldin óbærileg vegna leiðindanna sem henni fylgja: við verðum að losna undan pví ástandi og grátbiðja um læti og ringulreið. Pví að annað hvort hugsum við um eymdina sem við pekkjum eða pá eymd sem vofir yfir okkur. Og pótt við værum í skjóli fyrir allri eymd pá tækju leiðindin sér pað bessaleyfi að spretta út úr dýpstu

13 a Pegar Pyrrhus var ráðlagt að njóta hvíldar, í stað pess að útkeyra sig, reyndist honum erfitt að fylgja pví.

14 b Hégómleikinn, ánægjan sem felst í sýna öðrum hana [bráðina? Aths. pýð.].

15 c Dans: pað er nauðsynlegt að hugsa vel um hvar maður setur fæturna.

16 d Aðalsmaðurinn trúir í einlægni að veiðar séu göfug ánægja og konungleg. En sá sem rekur hundana áfram er ekki á sömu skoðun. 
fylgsnum hjartans par sem náttúrulegar rætur peirra liggja, og fylla hugann af eitri sínu. B.

Pví er pað svo að maðurinn er svo vesæll að honum leiðist án pess að nokkuð valdi honum leiðindum vegna pess hvernig eðli hans er. Og hann er svo hégómlegur að pótt hann búi yfir púsund grundvallarástæðum fyrir pví að finna til leiðinda mun jafnvel eitthvað smáræði eins og biljarðkjuði og kúla sem hann ýtir áfram duga til pess að lyfta honum upp. ${ }^{17 a}$

Hvernig má pað vera að pessi maður sem missti einkason sinn fyrir örfáum mánuðum og sem var svo örvæntingarfullur í morgun vegna deilna og dómsmála, er nú farinn að hugsa um eitthvað annað? Látið pað ekki koma ykkur á óvart, hann er með allan hugann við ferðir villisvíns sem hundarnir hafa elt af ofsa síðustu sex klukkustundir: pað parf ekki meira til. Рað er sama hversu mæddur maðurinn er, ef hægt er að sannfæra hann um að skemmta sér pá er hann hamingjusamur á meðan pað varir; og pað er sama hversu hamingjusamur maðurinn er, ef honum er ekki skemmt og ef hann er ekki upptekinn af einhverri ástríðu eða dægradvöl sem kemur í veg fyrir að leiðindin nái tökum á honum, verður hann fljótt mæddur og leiður. Án skemmtunar er engin gleði; með skemmtun er engin hryggð; og pað er líka pað sem mótar hamingju fólks. D. af háum stigum er að pað fólk hefur fjölda manns sér til skemmtunar og bolmagn til bess að viðhalda sér í pví ástandi.

Takið vel eftir, pví hvað annað er fólgið í pví að vera ráðherra, dómsmála-

17 a En hvert er markmið hans með pessu öllu, munt pú spyrja? Раð að hreykja sér næsta dag með vinum sínum af pví að hafa spilað betur en hinir. Pannig svitna menn á vinnustofum sínum til pess að geta sýnt lærðum mönnum að peir hafi leyst algebrudæmi sem enginn hefur fundið lausn við, og margir aðrir setja sjálfa sig í lífshættu til pess að geta hreykt sér af pví að hafa náð virki á sitt vald, sem mér finnst vera jafnmikill kjánaskapur. Og að lokum eru peir sem keppast við að fylgjast með pessu öllu, ekki til pess að verða vitrari heldur einungis til pess að sýna að peir viti petta allt saman. Og peir eru mestu kjánarnir í hópnum vegna pess að peir vita að peir eru kjánar, en um hina mætti halda að peir væru pað ekki ef peir áttuðu sig á pví. Einn maður lifir lífi sínu án leiðinda með pví að spila dálítið dag hvern. Gefið honum á hverjum morgni pað fé sem hann getur unnið í spilum daglega með pví skilyrði að hann spili ekki og pú munt valda honum óhamingju. Kannski léti einhver pau orð falla að hann væri á höttunum eftir ánægjunni af leiknum en ekki ávinningnum. Látið hann pá spila, en ekki fyrir peninga, og honum mun ekki finnast pað spennandi og honum mun leiðast: pað er pví ekki bara gamanið sem hann sækist eftir, langdregið og dauflegt gaman mun valda honum leiðindum. Hann parf að verða ákafur og að blekkja sjálfan sig með pví að ímynda sér að hann verði hamingjusamur við að vinna pað sem hann myndi ekki vilja að honum væri gefið með pví skilyrði að hann spilaði ekki, til pess að hann verði kappsamur og beini prá sinni, reiði og ótta að pessu viðfangi sem hann hefur búið sér til, eins og börnin sem verða hrædd við sitt eigið andlit sem pau hafa pakið málningu. 
ráðherra, pingforseti en pað hlutskipti að fá, árla dags, fjölda manns úr öllum áttum sem hindra viðkomandi í að hugsa um sjálfan sig svo lengi sem eina klukkustund. Og pegar peir falla í ónáð og eru sendir á sveitasetur sín par sem pá skortir hvorki efni né pjóna til pess aðstoða pá við nauðsynjar, eru peir stöðugt vesælir og telja sig vera afskiptir vegna pess að enginn kemur í veg fyrir að peir leiði hugann að sjálfum sér.

\section{7}

Skemmtun.

Er konungleg tign í sjálfu sér ekki næg beim sem hana hefur til að gera hann hamingjusaman, með pví einu að virða hana fyrir sér? Parf að beina huga hans frá pessari hugsun eins og á við um venjulegt fólk? Mér er vel ljóst að pað er hægt að gera mann hamingjusaman með pví að beina hugsun hans frá eymdinni heima fyrir og láta hug hans allan snúast um að dansa vel, en gildir раð sama um konung og verður hann hamingjusamari við pað að helga sig pessum hégómlegu skemmtunum en við pað að virða fyrir sér eigin mikilleika? Og hvað gæti veitt honum meiri ánægju? Væri pað ekki til að spilla gleði hans að pvinga sál hans til að stíga í takt við lag eða að koma höggi á bolta, í stað pess að leyfa honum að njóta pess að virða fyrir sér í næði pá tignu dýrð sem umlykur hann? Látum á pað reyna, látum konunginn vera einan án pess að nokkuð gleðji skilningarvit hans, án nokkurs hugðarefnis, án félagsskapar, pannig að hann geti hugsað um sjálfan sig óhindrað, og pá munum við sjá að konungur án skemmtunar er vesæll maður. Pví er vandlega reynt að komast hjá pví og konungar eru pess vegna ávallt umkringdir fjölda manns sem sjá til pess að skemmtun taki við af störfum peirra og sem vaka yfir pví í öllum frítíma konunga að veita peim ánægju og leiki til pess að ekki myndist tómarúm. Peir eru pannig umkringdir fólki sem gerir allt sem í pess valdi stendur til að koma í veg fyrir að konungurinn sé einn og í peirri stöðu að geta hugsað um sig sjálfan, vitandi að sú hugsun mun gera hann auman prátt fyrir að hann sé konungur.

Í pessu samhengi er ég alls ekki að tala um kristna konunga sem kristna menn, heldur einungis sem konunga.

Skemmtun.

Рað er auðveldara að pola dauðann án pess að hugsa um hann heldur en að pola hugsunina um dauðann án hættu. 
Skemmtun.

Frá bernsku er mönnunum falið að vaka yfir heiðri sínum, eigum, vinum, og pá yfir heiðri og eigum vina sinna; á pá er hlaðið alls kyns verkefnum, peir purfa að læra tungumál og ípróttir og peim er leitt fyrir sjónir að peir geti ekki vænst pess að vera hamingjusamir nema heilsa peirra, heiður, aleiga peirra og vina peirra, sé sem skyldi; og vanti upp á eitt af pessu verði peir óhamingjusamir. Pví eru peim falin verkefni og skyldur sem valda beim áhyggjum frá dagrenningu.

- Ja hérna, segðir pú, petta er undarleg leið til pess að gera pá hamingjusama; hvað væri betur fallið til pess að valda peim óhamingju?

- Hvað áttu við? Hvað væri betur til pess fallið? Рað væri nóg að taka af peim allt petta ómak pví að pá sæju peir sig sjálfa, peir myndu hugsa um hvað peir væru, hvaðan peir kæmu, hvert peir stefndu, og af peim sökum er ekki hægt að fela peim of mörg störf og dreifa huga peirra um of. Og pað er ástæða pess, að eftir að hafa fengið peim svo mörg verkefni, að peim er ráðlagt, ef peir hafa einhverja auða stund, að nota hana sér til skemmtunar og leiks og að beita sér ætíð af lífi og sál.

Hjarta mannsins er sannarlega innantómt og fullt viðbjóðs. 


\section{Hvernig pekkingin fer frá manninum til Guðs}

182

Fordómar sem leiða í villu.

Раð er sorglegt að sjá að allir láta sér nægja að velta vöngum um leiðir en ekki um markmið. Hver og einn hugsar um hvernig hann eigi að takast á við hlutskipti sitt, en pað er hendingin sem ræður hlutskiptinu og föðurlandinu.

Рað er dapurlegt að sjá svo marga Tyrki, villutrúarmenn og heiðingja fylgja í fótspor feðra sinna af peirri ástæðu einni að pað hefur verið haft fyrir peim að pað sé besta leiðin og pannig ákvarðast hlutskipti hvers og eins, lásasmiðs, hermanns, o.s.frv.

Рað er pess vegna sem villimönnum stendur á sama um hina Guðlegu forsjón.

183

Hvers vegna er pekking mín takmörkuð, stærð mín, ævi mín við hundrað ár frekar en púsund? Hvað vakti fyrir náttúrunni að gera mig svona og velja pennan stað frekar en annan í óendanleikanum, par sem ekki er ríkari ástæða til pess að velja einn frekar en annan, par sem ekkert freistar meira en annað.

[Lítið af öllu.

[Par sem við getum ekki verið altæk og státað okkur af að vita allt sem hægt er að vita um allt, verðum við að vita lítið um allt, vegna pess að pað er ákjósanlegra að vita dálítið um allt heldur en allt um eitthvað eitt. Pessi almenna pekking er best. Ef við gætum búið yfir hvoru tveggja væri pað enn betra, en ef velja parf annað hvort pá er pað petta sem við eigum að velja. Og fólk veit pað og gerir pað vegna pess að fólk hefur iðulega góða dómgreind.

[Skap mitt veldur pví að ég poli ekki pá sem kvakka eins og froskar og blása pegar peir borða. Skapið vegur pungt. Hver er ávinningur af pví? Eigum við að fylgja pessum punga vegna pess að hann er náttúrulegur? Nei, við eigum að veita honum viðnám.

[Ekkert sýnir betur hégómleika mannanna en vangaveltur um ástæður og áhrif ástarinnar, vegna pess að allur heimurinn hefur breyst af hennar völdum. Nef Kleópötru.] 


\section{H.5.}

Pegar ég sé blindu og vesöld mannanna, pegar ég horfi á pöglan alheiminn og manninn án pekkingar, upp á sjálfan sig kominn og sem áttavilltan í pessum afkima heimsins án pess að vita hver kom honum fyrir parna, hvað hann á af sér að gera, hvað verður um hann pegar hann deyr, ófæran um alla vitneskju, pá verð ég skelfingu lostinn eins og maður sem fluttur hefur verið sofandi á ógnvekjandi eyðieyju og vaknar án pess að vita <hvar hann er staddur> og á sér enga undankomuleið. Og pess vegna dáist ég að pví að við skulum ekki fyllast örvæntingu yfir pessu vesæla ástandi. Ég sé aðrar manneskjur nálægt mér sem eru svipaðrar náttúru. Ég spyr pær hvort pær séu betur upplýstar en ég. Pær svara pví neitandi og pví næst hafa pessar vesælu villuráfandi sálir litið í kringum sig og komið par auga á ánægjuleg viðfangsefni, og pær hafa gefið sig að peim og bundist peim. Нvað mig varðar pá hef ég ekki getað bundist peim og pegar ég virti fyrir mér hversu yfirborðsleg pau eru og lítið í peim að finna annað en pað sem má sjá, gáði ég hvort Guð hefði skilið par eftir einhver ummerki.

Ég sé ólík og andstæð trúarbrögð, og par með eru pau öll fölsk að einum undanskildum. Öll trúarbrögð vilja að peim sé fylgt vegna vægis peirra og hafa í hótunum við pá sem eru vantrúaðir. Ég fylgi ekki trúarbrögðum vegna hótana. Petta geta allir sagt. Allir geta póst vera spámenn, en ég sé kristnina og par finn ég spádóma, og pað er ekki öllum fært.

\section{5}

H.9.

Misræmi mannsins.

[Hingað komumst við með okkar náttúrulegu vitneskju. Ef hún er ekki sönn pá er engan sannleika að finna í manninum og ef hún er sönn pá er par að finna tilefni auðmýkingar; í báðum tilvikum parf hann að sætta sig við auðmýkingu.

[Og úr bví að maðurinn getur ekki lifað án pessarar vitneskju, óska ég pess, áður en við hefjum miklar rannsóknir á náttúrunni, að hann virði náttúruna fyrir sér af alvöru og af yfirvegun, að hann líti einnig í eigin barm, og sjái hlutföllin par á milli.]

Maðurinn ætti pví að virða náttúruna fyrir sér í allri hennar háleitu tign og beina sjónum sínum frá peim lágkúrulegu hlutum sem umkringja hann. 
Hann ætti að horfa á petta skæra ljós sem er eins og lampi sem lýsir upp alheiminn, jörðina ætti hann að sjá sem punkt í samanburði við hina geysistóru braut sólarinnar, hann ætti að furða sig á pví að pessi víðfeðma braut er aðeins örlítil í samanburði við pær sem stjörnur himinhvolfsins fylgja á ferðum sínum. En ef sýn okkar lætur staðar numið við petta, megi pá ímyndunaraflið taka við og horfa lengra; pað mun preytast af pví að taka við og skilja, en náttúran mun halda áfram að færa pví efni til umhugsunar. Allur hinn sjáanlegi heimur er ekki nema ógreinilegt strik í hinum stóra faðmi náttúrunnar. Engin hugmynd kemst nálægt honum; pað er til lítils fyrir okkur að belgja skynjunina út fyrir pað rúm sem við getum ímyndað okkur, pað eina sem við búum til eru frumeindir í samanburði við raunveruleikann. Hvolfið er óendanlegt og miðja pess er alls staðar, útjaðarinn hvergi. Pegar allt kemur til alls pá er helsta skynjanlega einkennið um almætti Guðs einmitt bað að ímyndun okkar fer villur vegar í pessari hugsun.

Megi maðurinn, pegar hann lítur í eigin barm, hugleiða hvað hann er í samanburði við pað sem er, megi hann líta á sig sjálfan sem villuráfandi í pessum afkima náttúrunnar, og megi hann, úr pessari litlu dýflissu sem hann býr í, og par á ég við alheiminn, læra að meta jörðina, konungsríkin, borgirnar og sig sjálfan að verðleikum.

Hvað er maður í óendanleikanum?

En til pess að finna annað furðuverk sem kemur jafn mikið á óvart, pá ætti hann að leita að pví allra viðkvæmasta í pví sem hann pekkir og pá getur smámaur sýnt honum í sínum undursmáa líkama líffæri sem eru enn smærri, fótleggi með liðamótum, æðar í fótleggjunum, blóði ææunum, vökva í blóðinu, dropa í vökvunum, gufu í dropunum. Ef hann heldur áfram að kljúfa petta niður í einingar með pessum hætti verður hann úrvinda af pví að hugsa um pað og gerum nú pað síðasta sem hann kæmist að, að umfjöllunarefni okkar núna. Hann mun e.t.v. hugsa sem svo að petta séu allra smæstu einingar náttúrunnar.

Ég vil að í pessu sjái hann nýtt hyldýpi. Ég vil ekki einungis draga upp fyrir hann mynd af hinum sjáanlega heimi heldur af víðerni náttúrunnar sem hægt er að skynja innra með pessari undursmáu frumeind; ég vil að hann sjái óendanlega marga heima sem hver hefur sinn himin, sínar plánetur, sína jörð, í sömu hlutföllum og hinn sýnilegi heimur, á pessari jörð dýranna, og að lokum smámaura par sem hann mun finna pað sama og hann fann í hinum fyrri og í peim mun hann einnig finna pað sama, endalaust og án afláts; ég vil að hann týni sér í pessum dásemdum sem eru jafn heillandi í smæð sinni og aðrar eru í umfangi sínu; vegna pess að hver getur ekki dáðst að pví að líkami 
okkar, sem fyrir stuttu var ekki greinanlegur í alheiminum sem sjálfur var ógreinanlegur í miðju alls, sé núna risavaxinn, heill heimur eða öllu frekar heild með hliðsjón af neindinni sem við komumst ekki að? Sá sem horfir pannig á sig vekur ótta með sjálfum sér; og bar sem hann horfir á sig borinn uppi af massanum sem náttúran gaf honum milli hyldýpanna tveggja, neindarinnar og óendanleikans, mun hann skjálfa andspænis pessum furðum og ég held að forvitni hans muni breytast í aðdáun og að hann verði líklegri til pess að virða pau fyrir sér í pögn heldur en að forvitnast um pau af yfirlæti.

Pví hvað er maður í náttúrunni, pegar allt kemur til alls? Neind, með hliðsjón af óendanleikanum, heild með hliðsjón af neindinni, miðja á milli einskis og alls, óendanlega langt frá pví að skilja pað sem er á ystu mörkum. Tilgangur hluta og forsendur verða honum ávallt huldar og umluktar órjúfanlegri leynd.

Hann er jafn ófær um að sjá tómið sem hann er sprottinn úr og óendanleikann sem gleypir hann; hvað gerir hann pví annað en að greina eitthvað sem er mitt á milli, í eilífri örvæntingu um að pekkja hvorki forsendu hlutanna né tilgang? Allir hlutir eiga uppruna sinn í neindinni og berast að óendanleikanum. Hver fylgist með pessari óvæntu ferð? Höfundur pessara dásemda skilur pær. Enginn annar er fær um pað.

Par sem mennirnir hafa ekki áttað sig á pessum óendanleika, hafa peir glaðbeittir snúið sér að pví að rannsaka náttúruna eins og peir geti mælt hlutföll sín við hennar.

Раð er undarlegt að peir hafi viljað skilja frumforsendur hluta og öðlast pannig skilning á öllu, af stærilæti sem er jafn óendanlegt og viðfang peirra. Pví að pað er enginn efi á pví að ekki er hægt að hafa slík áform án oflætis eða án pess að hafa óendanlega getu, eins og náttúran.

Sá sem hefur notið menntunar skilur að par sem náttúran hefur greypt ímynd sína og ímynd pess sem bjó hana til í alla hluti, pá eiga peir nánast allir hlutdeild í tvöföldum óendanleika hennar. Pannig sjáum við að öll vísindi eru óendanleg með tilliti til rannsóknasviðs peirra; hver efast um að rúmfræðin, til dæmis, búi yfir óendanlegum óendanleika af yrðingum? Pau eru einnig óendanleg hvað varðar fjölda og blæbrigði forsendna peirra og hverjum er ekki ljóst að pau standa ekki ein og sjálf en hvíla á öðrum sem hvíla á enn öðrum og eru pví aldrei pau síðustu?

En um pau síðustu sem skynsemin nemur fjöllum við eins og um efnislega hluti sé að ræða pegar við segjum að punktur sé ókljúfanlegur ef skynfæri okkar eru ekki lengur fær um að greina nokkurn skapaðan hlut, pó svo að punktinn megi kljúfa óendanlega og pað liggi í eðli hans. 
Af pessum tveimur gerðum óendanleikans í vísindum er sá sem lýtur að stærð skynjanlegri og af peim sökum hafa fáar manneskjur póst vita allt. „Ég xtla að tala um allt," sagði Demokritos.

En óendanleikinn í smæðinni er ekki eins sýnilegur. Heimspekingarnir hafa iðulega póst skilja hann og par hefur peim öllum orðið á í messunni. Pannig hafa pessir kunnuglegu titlar séð dagsins ljós, Um frumforsendur blutanna, Um frumforsendur beimspekinnar, og fleiri í pessum dúr, í raun jafn íburðarmiklir pótt peir virðist ekki vera pað, og pessi sem sker í augun: De omni scibili [Um allt sem hagt er að vita].

Við teljum okkur af náttúrunnar hendi eiga auðveldara með að komast að kjarna hlutanna en að átta okkur á ummáli peirra, og hið sýnilega umfang heimsins er greinilega ofar okkar getu. En par sem við erum stærri en smáir hlutir teljum við okkur fær um að skilja pá, engu að síður krefst pað jafnmikillar færni að nálgast neindina og að nálgast heildina. Færnin verður að vera óendanleg í báðum tilvikum, og mér virðist sem svo að sá sem gæti skilið hinstu rök hlutanna gæti einnig skilið óendanleikann. Neindin og óendanleikinn eru háð hvort öðru, annað leiðir til hins. Pessi endimörk snertast og sameinast vegna pess hversu fjarlæg pau eru hvort öðru, og pau eru bæði í Guði, og aðeins í Guði.

Við purfum pví að pekkja mörk okkar. Við erum eitthvað og við erum ekki allt. Sú tilvera sem við eigum rænir okkur pekkingu á frumforsendum sem spretta úr neindinni, og pessi litla tilvera sem við eigum kemur í veg fyrir að við getum séð óendanleikann.

Greind okkar hefur sama stað í skipan skiljanlegra hluta og líkami okkar hefur í víðfeðmi náttúrunnar.

Við erum takmörkuð að öllu leyti og pessi staða, í miðju tveggja endamarka, setur svip sinn á alla færni okkar. Skilningarvit okkar skynja ekkert sem er á ystu mörkum, of mikill hávaði slævir heyrn okkar, of mikil birta blindar okkur, of mikil fjarlægð og of lítil fjarlægð koma í veg fyrir að við getum séð. Sé mál of langt eða of stutt verður pað torskilið, of mikill sannleikur kemur okkur úr jafnvægi. Ég pekki fólk sem getur ekki skilið að séu fjórir dregnir frá núlli pá er útkoman núll. Frumforsendurnar eru of augljósar fyrir okkur; of mikil ánægja veldur ópægindum, of mikill samhljómur spillir tónlistinni, og of mikið af góðverkum skapraunar fólki. Við viljum eiga nóg fyrir skuldinni: „Beneficia eo usque laeta sunt dum videntur exsolfi posse; ubi multum antevenere, pro gratia odium redditur." (Góðvild er vel pegin svo lengi sem við getum endurgoldið hana; ef hún fer yfir pau mörk breytist 
pakklæti í pykkju. $)^{18}$ Við finnum hvorki mikinn hita né mikinn kulda; öfgafullir eiginleikar eru óvinir okkar og við skynjum pá ekki, við finnum pá ekki lengur, peir valda okkur pjáningu. Of mikil æska og of mikil elli hindra hugann, of mikill og of lítill lærdómur.

Að lokum pá eru pau fyrirbæri sem eru á ystu mörkum ekki til fyrir okkur og við erum ekki til fyrir peim; pau eru fyrir utan okkar skilning eða við utan peirra.

Svona er okkar raunverulega ástand. Рað gerir okkur ófær um að vita með vissu og að vera algerlega ókunnugt um eitthvað. Við reikum um víðfeðma miðju, alltaf óviss og óstöðug, og okkur er ýtt frá einum endanum til hins; höfum við ætlað að bindast einhverjum áfangastað og safna kröftum pá er hann óstöðugur og hverfull, og ef við eltum hann smýgur hann ávallt úr höndum okkur, rennur frá okkur og er á eilífum flótta; ekkert nemur staðar fyrir okkur. Petta er okkar náttúrulega ástand og engu að síður er pað andstætt löngunum okkar. Við brennum af prá til að eiga samastað og trausta endastöð par sem við getum reist turn sem nær upp í óendanleikann, en öll undirstaða okkar brestur og jörðin opnast niður í hyldýpi.

Leitum pví hvorki að vissu né traustleika: skynsemi okkar verður fyrir sífelldum vonbrigðum vegna hverfulleika pess sem sýnist; ekkert getur fest hið endanlega milli tveggja óendanleika sem loka pað inni og flýja pað.

Pegar við höfum skilið petta held ég að við getum unað sátt, hvert og eitt par sem náttúran kom okkur fyrir.

Par sem pessi miðja sem er okkar sameiginlega hlutskipti er ætíð langt frá endamörkunum, hverju skiptir pá pótt einhver hafi aðeins meiri pekkingu á hlutunum; ef svo er lítur hann á pá úr örlítið meiri hæð; en er hann ekki alltaf jafn óendanlega langt frá markinu? Og er ekki lífshlaup okkar jafn örstutt pótt tíu ár bætist við? Í augum óendanleikans er allur endanleiki eins, sama hver hann er, og ég veit ekki af hverju við ættum að beina ímyndunaraflinu frekar í eina átt en aðra.

Allur samanburður okkar við endanleikann veldur okkur angri.

Ef maðurinn byrjaði á pví að rannsaka sjálfan sig sæi hann hversu ófær hann er um komast lengra. Hvernig gæti hluti pekkt Heildina? En hann mun ef til vill prá að pekkja að minnsta kosti pá hluta sem hann getur mælt hlutföll sín við. En heimurinn er gerður úr hlutum sem allir tengjast og fléttast hver við annan pannig að ég held að ómögulegt sé að pekkja einn hluta án pess að pekkja annan og án pess að pekkja Heildina.

18 Tacitus, Annálar, IV, 18; Michel de Montaigne, Essais, III, 8. 
Maðurinn, til dæmis, tengist öllu pví sem hann pekkir. Hann parfnast staðar til pess að vera á, tíma til pess að vara, hreyfingar til pess að lifa, frumefna sem hann er búinn til úr, hann parf hita og fæðu til að nærast, loft til pess að anda. Hann sér ljósið, hann finnur efnið, allt tengist honum á einhvern hátt. Pví er nauðsynlegt, til pess að pekkja manninn, að vita hvernig á pví stendur að hann parfnist lofts til pess að lifa, og til pess að pekkja loftið, vita hvernig pað tengist með pessum hætti lífi mannsins, o.s.frv.

Loginn lifir ekki án lofts; pví purfum við að pekkja annað til að pekkja hitt.

Par sem allir hlutir eru pannig af völdum einhvers og valda einhverju, peim er hjálpað og peir hjálpa, peir eru óbeinir og beinir, og allir tengjast peir náttúrulegum og óskynjanlegum tengslum sem binda saman pá fjarlægustu og ólíkustu, tel ég að pað sé ógerningur að pekkja hluta án pess að pekkja heildina, og á sama hátt er ógerningur að pekkja heildina án pess að pekkja hlutana hvern fyrir sig.

[Eilífð hlutanna sjálfra eða í Guði hlýtur einnig að koma okkur sem erum svo skammlíf, á óvart. Hinn stöðugi óhreyfanleiki náttúrunnar, <í> samanburði við pær sífelldu breytingar sem eiga sér stað í okkur, hlýtur að hafa sömu áhrif.]

Og pað sem rekur smiðshöggið á vangetu okkar til pess að pekkja hluti er að peir eru einfaldir í gerð en við erum samsett úr tveimur andstæðum náttúrum og af ólíkum toga, sál og líkama. Vegna pess að pað er ómögulegt að sá hluti okkar sem er skynsamur sé annað en andlegur; og ef við pættumst ekki vera annað en líkami myndi pað útiloka okkur enn frekar frá pví að pekkja hlutina, pví að ekkert er jafn óhugsandi og að segja að efnið pekki sig sjálft. Okkur er ómögulegt að vita hvernig pað pekkir sig sjálft.

Og með pessum hætti, ef við <erum> einungis efnisleg, getum við ekki vitað neitt, og ef við erum sett saman úr anda og efni getum við ekki pekkt til fulls einfalda hluti, hvort sem peir eru andlegir eða efnislegir.

Af peim sökum rugla næstum allir heimspekingar saman hugmyndum um pessa hluti og tala um efnislega hluti eins og peir væru andlegir og um andlega hluti eins og peir væru efnislegir, vegna pess að peir segja hiklaust að efnislegir hlutir leiti niður, að peir hverfist um miðju sína, að peir flýi eyðileggingu sína, að peir óttist tómið, að peir hafi prár, peim sé vel við eitthvað, illa við annað, og allt eru petta hlutir sem tilheyra einungis andanum. Og, sem peir tala um andann, líta peir svo á að hann sé á ákveðnum stað, og að hann geti færst úr einum stað í annan, en pað eru hlutir sem tilheyra einungis efnislegum hlutum. 
Í stað pess að fá hugmynd um pessa hluti í tærleika sínum, litum við pá með eiginleikum okkar og mörkum far okkar samsettu mannveru á alla einföldu hlutina sem við virðum fyrir okkur.

Hver stæði ekki í peirri trú, við pað að sjá okkur gefa öllum hlutum anda og efni, að pessi blanda væri okkur auðskiljanleg? Og samt er hún einmitt pað sem við skiljum hvað minnst: maðurinn sjálfur er undraverðasta viðfangsefni náttúrunnar vegna pess að hann getur ekki skilið hvað efni er og enn síður hvað andi er, og allra síst hvernig efni getur sameinast anda. Petta er pað sem reynist honum erfiðast og engu að síður er pað hann sjálfur: „modus quo corporibus adbaerent spiritus comprehendi ab bomine non potest, et boc tamen homo est" (pað hvernig andi sameinast efni er utan við skilning mannsins og samt er maðurinn pannig gerður). ${ }^{19}$

[Petta er ein peirra ástæðna sem gera manninn svo vanhæfan til pess að pekkja náttúruna. Hún er óendanleg á tvo vegu, hann er endanlegur og takmarkaður; hún varir og viðheldur sér óendanlega í tilveru sinni; hann staldrar stutt við og er dauðlegur. Einstakir hlutir spillast og breytast á hverju andartaki. Hann sér pá einungis pegar hann á leið hjá. Peir hafa forsendu og tilgang. Hann skilur hvorugt. Peir eru einfaldir en eðli mannsins er tvípætt.]

Að lokum, til pess að fullkomna pessa sönnun á veikleika okkar, eru hér tvö îhugunarefni ...

\section{6}

H.3.

Maðurinn er ekkert annað en reyr, sá veikasti í náttúrunni, en hann er reyr sem hugsar. Alheimurinn allur parf ekki að búast vopnum til pess að kremja hann; mistur eða vatnsdropi nægir til pess að drepa hann. En pó alheimurinn kremdi hann væri maðurinn enn göfugri en pað sem drepur hann vegna pess að hann veit að hann deyr og að heimurinn er máttugri en hann og pað veit alheimurinn ekkert um.

Reisn okkar er pess vegna alfarið fólgin í hugsuninni. Hún gerir okkur kleift að rísa upp, en hvorki rúmið né varanleikinn, sem við munum aldrei geta fyllt.

Einbeitum okkur að pví að hugsa vel: pað er forsenda siðferðisins.

19 Heilagur Ágústínus, Um borgríki Guðs, XXI, 10. 
Hin eilífa pögn hins óendanlega geims vekur mér ótta.

188

Látið huggast, ekki búast við að hann komi frá ykkur sjálfum, pvert á móti, með pví að búast ekki við neinu af ykkur sjálfum munuð pið öðlast hann. ${ }^{20}$

Ásdís R. Magnúsdóttir pýddi

20 Petta torskilda brot er hér pýtt með hliðsjón af skýringum á brotinu Transition $n^{\circ} 8 / 8$ sem finna má á vefsíðunni: Dominique Descotes og Gilles Proust, L'édition électronique des Pensées de Pascal, sótt 1. desember 2020 af http://penseesdepascal.fr/ Transition/Transition8-modernephp. Par er bent á að „hann“ vísi til pess skilnings á hinu sanna og hinu góða sem leitað er að í Hugsunum. Huggunin sé nauðsynleg pegar maðurinn hefur áttað sig á stöðu sinni í heiminum. 